\begin{tabular}{|l|l|l||}
\hline \multicolumn{2}{|c|}{ PublisherInfo } \\
\hline \hline PublisherName & $:$ & BioMed Central \\
\hline \hline PublisherLocation & $:$ & London \\
\hline \hline PublisherImprintName & $:$ & BioMed Central \\
\hline \hline
\end{tabular}

\title{
NSAIDs inhibit p38 MAPK activation
}

\begin{tabular}{||l|l|l||}
\hline \multicolumn{2}{|c|}{ ArticleInfo } \\
\hline \hline ArticleID & $:$ & 278 \\
\hline \hline ArticleDOI & $:$ & $10.1186 /$ ar-2002-75400 \\
\hline \hline ArticleCitationID & $:$ & 75400 \\
\hline \hline ArticleSequenceNumber & $:$ & 31 \\
\hline \hline ArticleCategory & $:$ & Paper Report \\
\hline \hline ArticleFirstPage & $:$ & 1 \\
\hline \hline ArticleLastPage & $:$ & 3 \\
\hline \hline & & RegistrationDate $: 2002-2-6$ \\
& $:$ & Received \\
ArticleHistory & Accepted 2002-2-6 \\
& $:$ 2002-2-20 \\
\hline \hline ArticleCopyright & $:$ & Biomed Central Ltd2002 \\
\hline \hline ArticleGrants & $:$ & \\
\hline \hline
\end{tabular}




\begin{tabular}{|l|l|l||}
\hline ArticleContext & $: 130754411$ \\
\hline
\end{tabular}

Cheryl Smythe, ${ }^{\text {Aff1 }}$

Affl Imperial College Faculty of Medicine, London, UK

\section{Keywords}

COX, MAPK, NSAID, PGE2, p38

\section{Context}

Nonsteroidal anti-inflammatory drugs (NSAIDs) inhibit cyclooxygenase (COX) activity. Predominantly acting on macrophages and neutrophils, they have also been shown to suppress T-cell proliferation, expression of surface markers of activation and the secretion of cytokines. NSAIDs mediate these immunosuppressive effects by blocking transcription factors such as nuclear factor of activated T cells (NF-AT) and NF-?B. The effects of NSAIDs on components of the T-cell antigen receptor (TCR) signalling cascade proximal to transcription factor activation were investigated in this study.

\section{Significant findings}

Inhibition of TCR-mediated NF-AT activation was used to assess the effect of NSAIDs on T-cell signalling. COX-1 and COX-2 -selective NSAIDs, or Erk and p38 mitogen activated protein kinase inhibitors, all reduced NF-AT activation, although COX-2 selective inhibitors only partially inhibited it. TCR-induced p38 activity was inhibited by both nonselective and COX-1 specific NSAIDs, but not by COX-2 specific inhibitors. Erk activity, however, was unaffected by NSAIDs. NSAIDs did not inhibit lipopolysaccharide- or $\mathrm{H}_{2} \mathrm{O}_{2}$-induced p38 activation; therefore, they specifically affect TCR-mediated p38 activation. NSAIDs had no effect on reactive oxygen species (ROS), implying that their effect on TCR-mediated p38 activation was downstream of ROS generation. Furthermore NSAIDs had no effect on the $\mathrm{Ca}^{2+}$ /calcineurin pathway that is also involved in the TCR activation of $\mathrm{p} 38$. Addition of prostaglandin $\mathrm{E}_{2}\left(\mathrm{PGE}_{2}\right)$ reversed NSAIDs inhibition of NF-AT activity, but did not overcome the inhibition of NF-AT activation by p38 inhibitors. Finally, inhibition of COX-1 blocked TCR-dependent COX-2 expression. 


\section{Comments}

Some of the molecular mechanisms that follow TCR engagement and their inhibition by NSAIDs are carefully dissected in this study. The pathway investigated is complex and therefore the manuscript would have benefited from a pictorial representation of the findings. The sequence of events leading to p38 and NF-AT activation following TCR activation is proposed as follows: TCR engagement, ROS generation, increased arachadonic acid production, induction of COX-1 activity and thus increased $\mathrm{PGE}_{2}$ production, $\mathrm{p} 38$ activation leading to NF-AT activity and subsequent COX-2 induction. Thus this study identifies a key role for COX-1 in mediating some of the early events of T-cell activation. Although a specific mechanism by which NSAIDs suppress T-cell activation has been elucidated here, the relevance of immunosuppressant activity of NSAIDs in T cells during disease is unclear, as NSAIDs do not display disease-modifying properties in rheumatoid arthritis. However, the authors also point out that their data suggest a role for specific p38 inhibitors as an alternative to classical T-cell immunosuppressants.

\section{Methods}

Luciferase assay, immunoblotting, measurement of reactive oxygen species, RT-PCR

\section{Additional information}

\section{References}

1. Paccani SR, Boncristiano M, Ulivieri C, D'Elios MM, Del Prete G, Baldari CT: Nonsteroidal antiinflammatory drugs suppress T-cell activation by inhibiting p38 MAPK induction. J Biol Chem. 2002, 277: 1509-1513.

This PDF file was created after publication. 